\title{
INVESTIGATION OF THE MECHANICAL PROPERTIES OF A CORK/RUBBER COMPOSITE
}

\author{
RAZISKAVA MEHANSKIH LASTNOSTI KOMPOZITA \\ PLUTA/GUMA
}

\author{
Radek Kottner ${ }^{1}$, Jiří Kocáb ${ }^{2}$, Jan Heczko ${ }^{2}$, Jan Krystek ${ }^{1}$ \\ ${ }^{1}$ University of West Bohemia, Faculty of Applied Sciences, European Centre of Excellence, NTIS - New Technologies for Information \\ Society, Univerzitní 8, 30614 Plzeň, Czech Republic \\ ${ }^{2}$ University of West Bohemia, Faculty of Applied Sciences, Department of Mechanics, Univerzitní 8, 30614 Plzeň, Czech Republic \\ kottner@kme.zcu.cz
}

Prejem rokopisa - received: 2015-07-01; sprejem za objavo - accepted for publication: 2015-07-28

doi:10.17222/mit.2015.172

This work was focused on the investigation of the mechanical properties of the ACM87 composite when subjected to a large strain. Simple tension, simple shear, simple compression, and volumetric compression tests were performed using a universal testing machine. Various strain rates were used. The material data necessary for the identification of the parameters of a finite-strain viscoelastic constitutive model, such as the Bergstrom-Boyce model, were obtained.

Keywords: cork, rubber, particle composite, Bergstrom-Boyce model, viscoelastic, large strain

Delo je usmerjeno v preiskavo mehanskih lastnosti kompozita ACM87, ki je bil izpostavljen veliki obremenitvi. Na univerzalnem preizkuševalnem stroju so bili izvršeni natezni, strižni, tlačni in volumetrični tlačni preizkusi. Uporabljene so bile različne hitrosti obremenjevanja. Dobljeni so bili podatki o materialu, ki so potrebni za postavitev parametrov konstitutivnega viskoelastičnega modela končne obremenitve, kot je Bergstrom-Boycev model.

Ključne besede: pluta, guma, kompozitni delec, Bergstrom-Boycev model, viskoelastičnost, velika obremenitev

\section{INTRODUCTION}

Cork/rubber composites are often used to damp vibrations before they are radiated as an acoustic noise and before they are transmitted to the other components of the system. An improvement of the damping properties of carbon-fibre reinforced plastics using an integration of the layers made of a cork/rubber composite or rubber, when subjected to small strain deformations, was proved. ${ }^{1-3}$ In these works, cantilever flat bars and square tubes were experimentally analysed. Similar cantilever beams were applied in the structure of a machine tool. The influence of the hybrid composite lay-up on the stiffness and damping of the cantilever beams was numerically investigated. ${ }^{1,2}$ The Rayleigh damping was considered in the numerical simulations.

Since this work is motivated by an application of the ACM87 (AMORIM cork/rubber particle composite) as a damping layer with much larger deformations (e.g., in helmets), a more accurate material model, which would be possible to use for finite-strain simulations, has to be used. The Bergstrom-Boyce model ${ }^{4}$ is one of the models suitable for elastomer modelling. This micromechanicsinspired theory successfully captures many time-dependent characteristics. Since cork has a cellular structure similar to foam ${ }^{5}$ it does not exhibit incompressibility (in contradistinction to rubber). Therefore, the aim of this work is to obtain experimental data for the identification

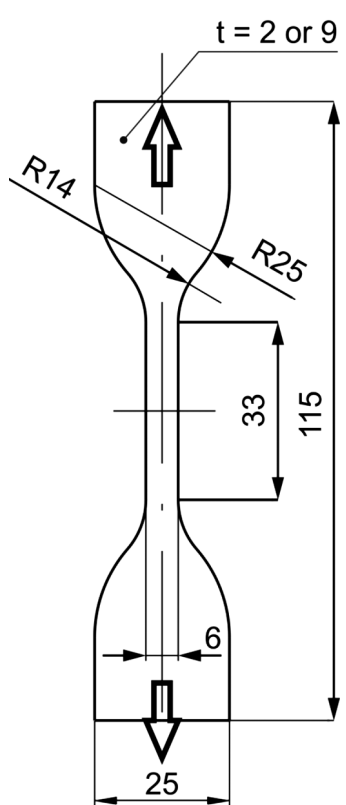

(a)

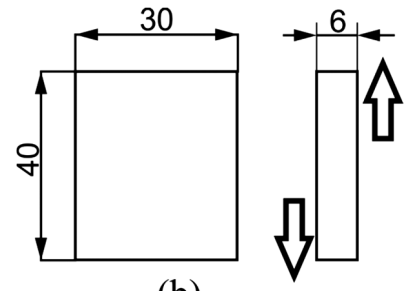

(b)

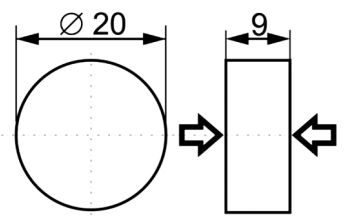

(c)

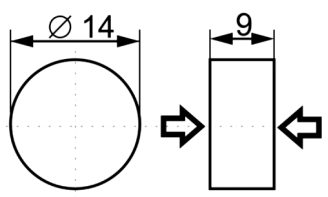

(d)
Figure 1: Experimental samples for: a) simple tension (T2 or T9), b) simple shear (S6), c) simple compression (C9), d) volumetric compression (V9)

Slika 1: Vzorci za preizkuse: a) enostaven nateg (T2 ali T9), b) enostavno striženje (S6), c) enostavno stiskanje (C9), d) volumetrično tlačenje (V9) 

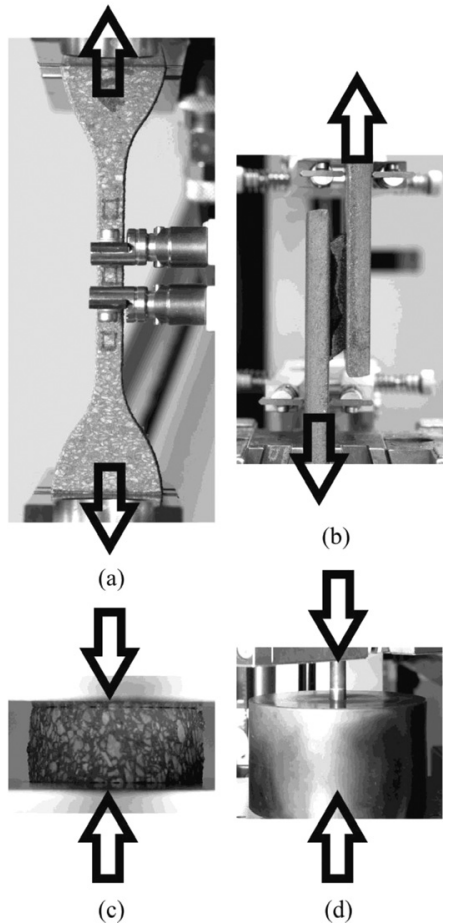

Figure 2: Performed tests: a) simple tension, b) simple shear, c) simple compression, d) volumetric compression

Slika 2: Izvedeni preizkusi: a) enostaven nateg, b) enostavno striženje, c) enostavno stiskanje, d) volumetrično tlačenje

of the parameters of a finite-strain viscoelastic constitutive model using simple tension, simple shear and simple compression tests (simple tests) according to ${ }^{6}$ and, in addition, using a volumetric-compression test.

\section{EXPERIMENTAL PART}

Experimental samples were cut from ACM87 plates using a water jet. The plates were (2,6 and 9) mm thick. The geometry and designation are obvious from Figure 1. The first symbol denotes the type of the test and the second symbol denotes the characteristic dimension. The strain rate is appended to these two symbols (e.g.,

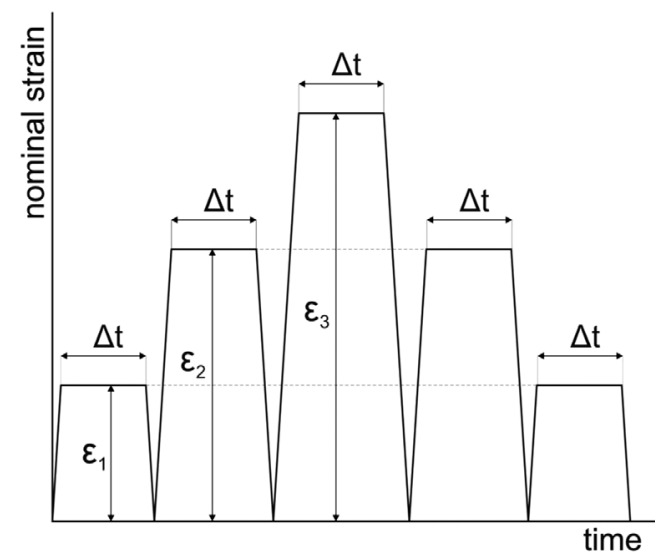

Figure 3: Applied-strain history

Slika 3: Zgodovina uporabljenega obremenjevanja

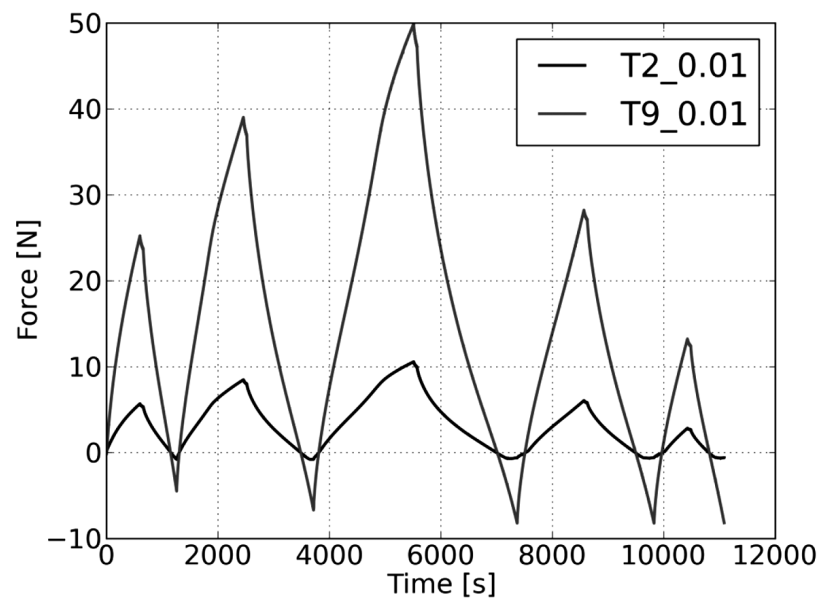

Figure 4: Force-time diagram, simple tension, strain rate of $0.01 \mathrm{~s}^{-1}$ Slika 4: Diagram sila-čas enostaven nateg, hitrost obremenitve $0,01 \mathrm{~s}^{-1}$

T2_0.10 is a tensile sample with a $2 \mathrm{~mm}$ thickness that was loaded at a $0.1 \mathrm{~s}^{-1}$ strain rate).

The tests were performed on a Zwick/Roell Z050 machine using $200 \mathrm{~N}$ or $50 \mathrm{kN}$ load cells (Figure 2). A contact-type extensometer with two sensor arms was used to measure displacements under the tensile $(T)$ and shear $(S)$ loading. The initial gage length in the case of the $\mathrm{T}$ test was $10 \mathrm{~mm}$. In the case of the $\mathrm{S}$ test, the relative displacement of the steel plates, the glue wasn't measured (it was used for the bonding of the steel plates and the samples), was measured using the Loctite 480 glue. Displacement during the compression tests was measured using an extensometer with one sensor arm that was placed on the moving platen (simple compression $-\mathrm{C}$ test) or on the moving grip where the piston was fixed (volumetric compression - V test).

At least three new intact samples (to enable the observation of the Mullins effect) were used for each test. The temperature was $23 \pm 1{ }^{\circ} \mathrm{C}$, the atmospheric moisture was $50 \pm 6 \%$.

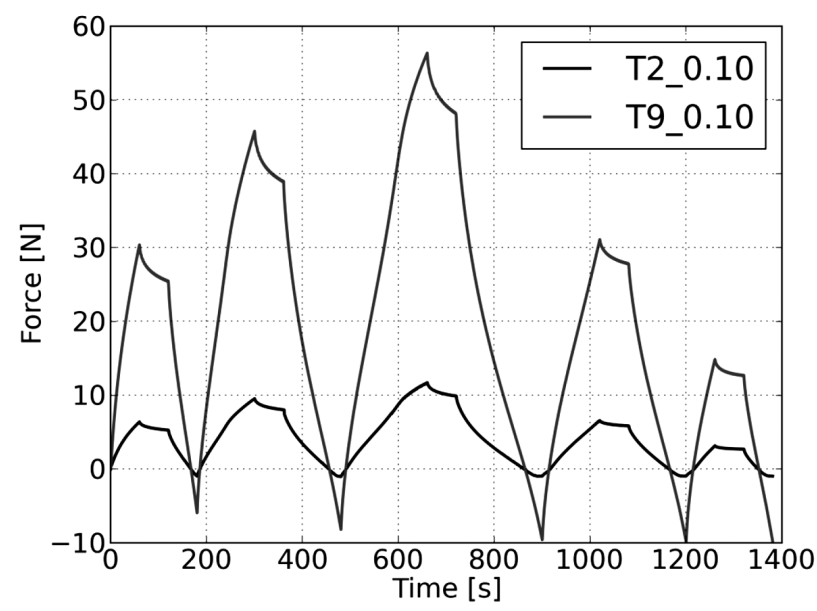

Figure 5: Force-time diagram, simple tension, strain rate of $0.1 \mathrm{~s}^{-1}$ Slika 5: Diagram sila-čas, enostaven nateg, hitrost obremenjevanja 0,1 $\mathrm{s}^{-1}$ 


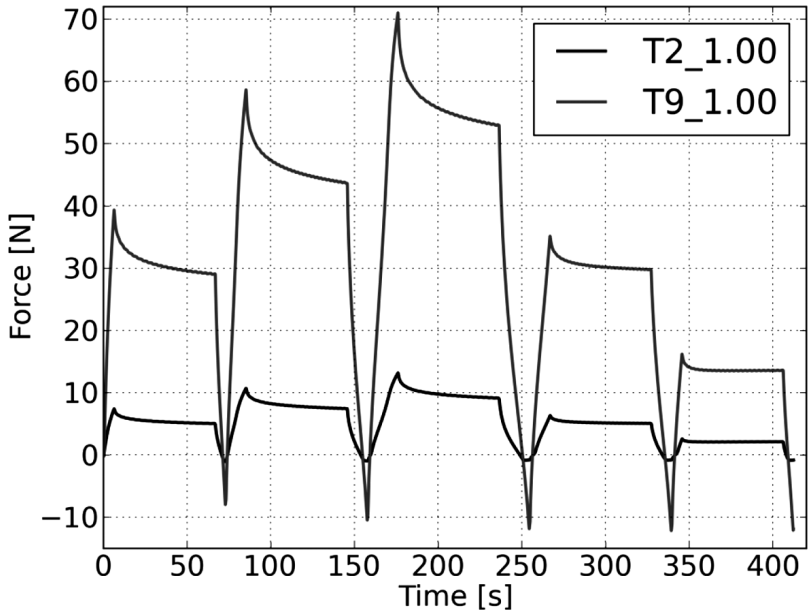

Figure 6: Force-time diagram, simple tension, strain rate of $1 \mathrm{~s}^{-1}$ Slika 6: Diagram sila-čas, enostaven nateg, hitrost obremenjevanja $1 \mathrm{~s}^{-1}$

The same nominal-strain history was applied in the T, $\mathrm{S}$ and $\mathrm{C}$ tests. ${ }^{6}$ The strain history is shown in Figure 3. Five loading/unloading cycles with values of the nominal strain $\varepsilon_{1}=10 \%, \varepsilon_{2}=20 \%$ and $\varepsilon_{3}=30 \%$ were performed. The relaxation time was $\Delta t=60 \mathrm{~s}$. The samples were loaded at three different nominal-strain rates: 0.01 $\mathrm{s}^{-1}, 0.1 \mathrm{~s}^{-1}$, and $1 \mathrm{~s}^{-1}$.

Only three cycles were performed during the $\mathrm{V}$ test. The maximum strain for all three cycles was $30 \%$. The relaxation time was $\Delta t=0 \mathrm{~s}$. All the $\mathrm{V}$ samples were loaded at a $0.02 \mathrm{~s}^{-1}$ strain rate.

\section{RESULTS AND DISCUSSION}

From the minimum of three samples for each test, typical force-time/displacement curves were selected and further processed.

Figures 4 to $\mathbf{1 2}$ show force-time $(F-t)$ curves for the simple tests. It is obvious that the forces relaxed significantly. Especially, when the strain rate was $0.1 \mathrm{~s}^{-1}$, the

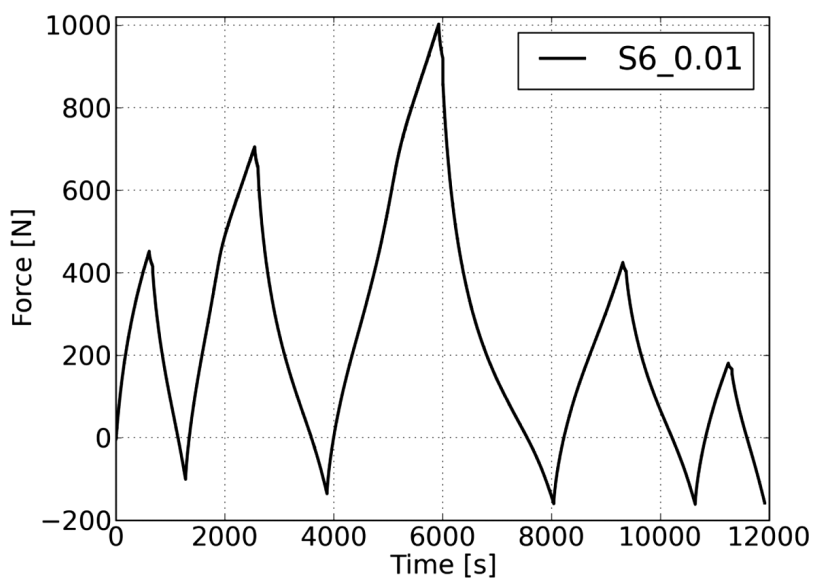

Figure 7: Force-time diagram, simple shear, strain rate of $0.01 \mathrm{~s}^{-1}$ Slika 7: Diagram sila-čas, enostavno striženje, hitrost obremenjevanja $0,01 \mathrm{~s}^{-1}$

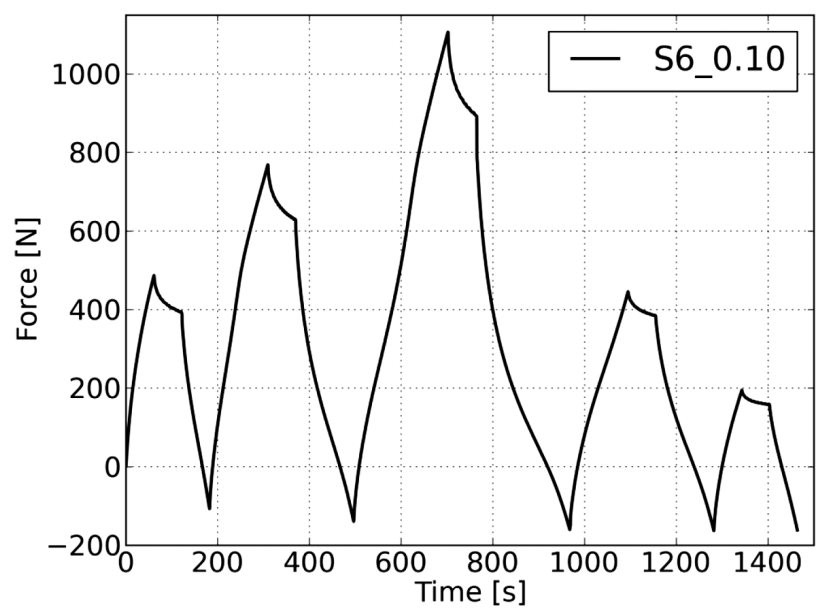

Figure 8: Force-time diagram, simple shear, strain rate of $0.1 \mathrm{~s}^{-1}$

Slika 8: Diagram sila-čas, enostavno striženje, hitrost obremenjevanja $0,1 \mathrm{~s}^{-1}$

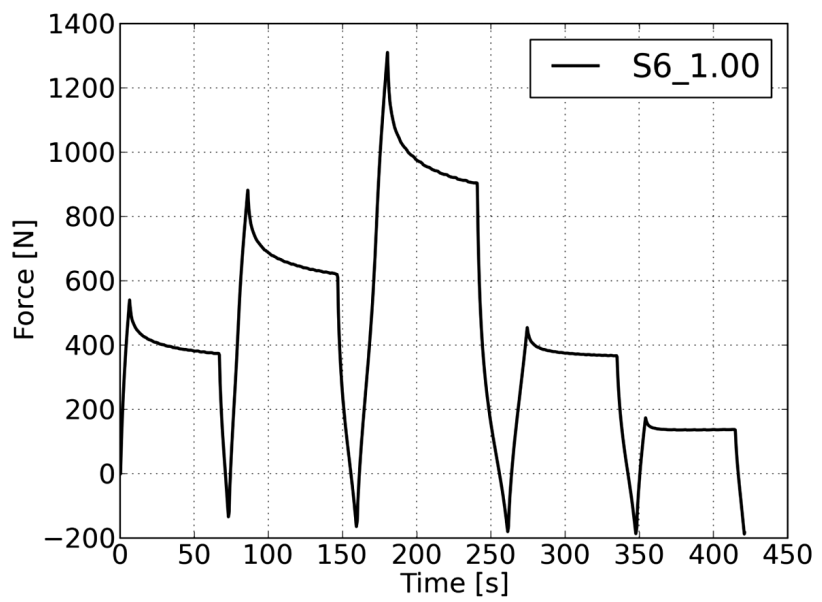

Figure 9: Force-time diagram, simple shear, strain rate of $1 \mathrm{~s}^{-1}$ Slika 9: Diagram sila-čas, enostavno striženje, hitrost obremenjevanja $1 \mathrm{~s}^{-1}$

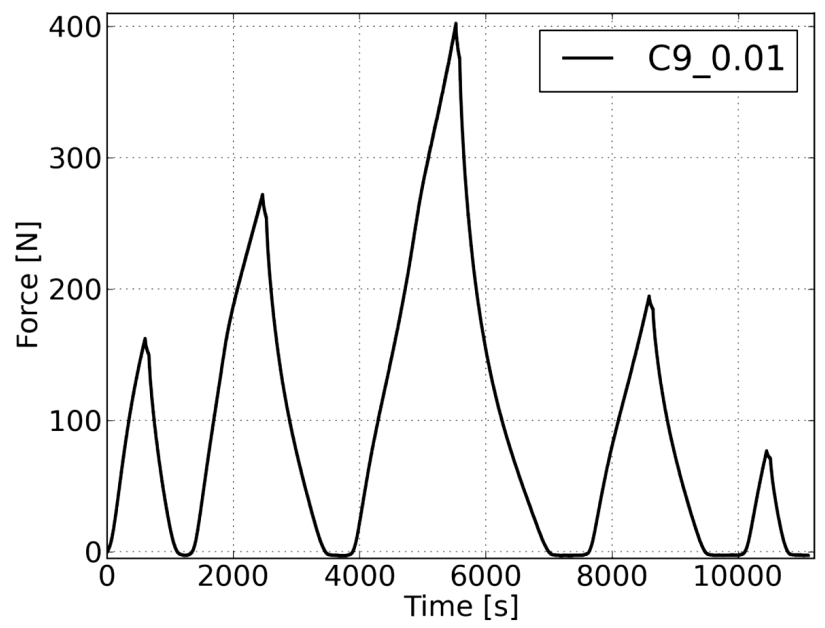

Figure 10: Force-time diagram, simple compression, strain rate of $0.01 \mathrm{~s}^{-1}$

Slika 10: Diagram sila-čas, enostavno tlačenje, hitrost obremenjevanja $0,01 \mathrm{~s}^{-1}$ 
R. KOTTNER et al.: INVESTIGATION OF THE MECHANICAL PROPERTIES OF A CORK/RUBBER COMPOSITE

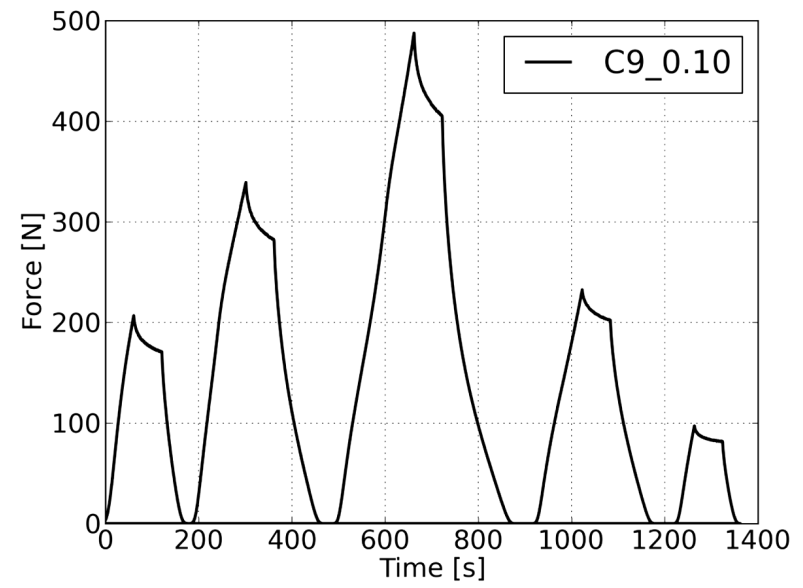

Figure 11: Force-time diagram, simple compression, strain rate of 0.1 $\mathrm{s}^{-1}$

Slika 11: Diagram sila-čas, enostavno tlačenje, hitrost obremenjevanja $0,1 \mathrm{~s}^{-1}$

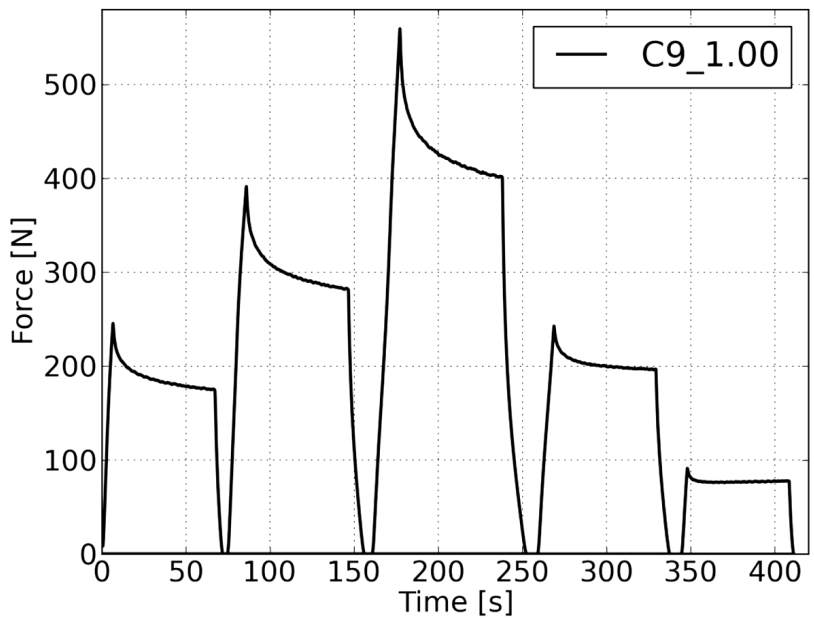

Figure 12: Force-time diagram, simple compression, strain rate of $1 \mathrm{~s}^{-1}$

Slika 12: Diagram sila-čas, enostavno tlačenje, hitrost obremenjevanja $1 \mathrm{~s}^{-1}$

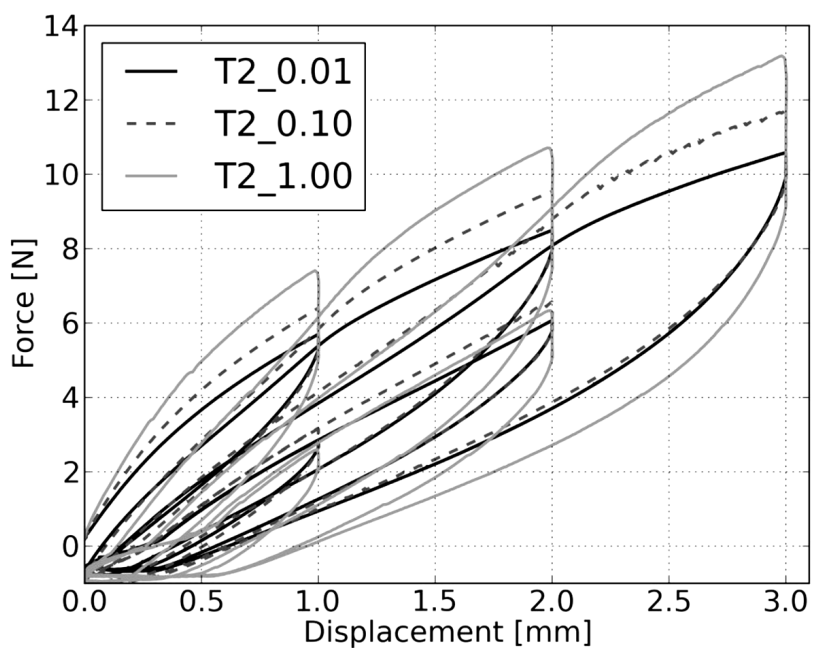

Figure 13: Force-displacement diagram, simple tension, various strain rates, sample thickness of $2 \mathrm{~mm}$

Slika 13: Diagram sila-raztezek, enostaven nateg, različne hitrosti obremenjevanja, debelina vzorca $2 \mathrm{~mm}$

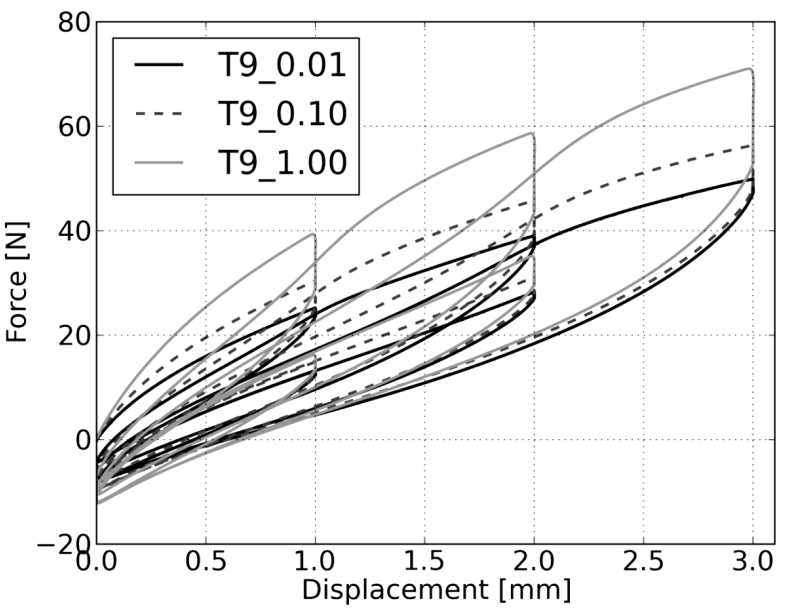

Figure 14: Force-displacement diagram, simple tension, various strain rates, sample thickness of $9 \mathrm{~mm}$

Slika 14: Diagram sila-raztezek, enostaven nateg, različne hitrosti obremenjevanja, debelina vzorca $9 \mathrm{~mm}$

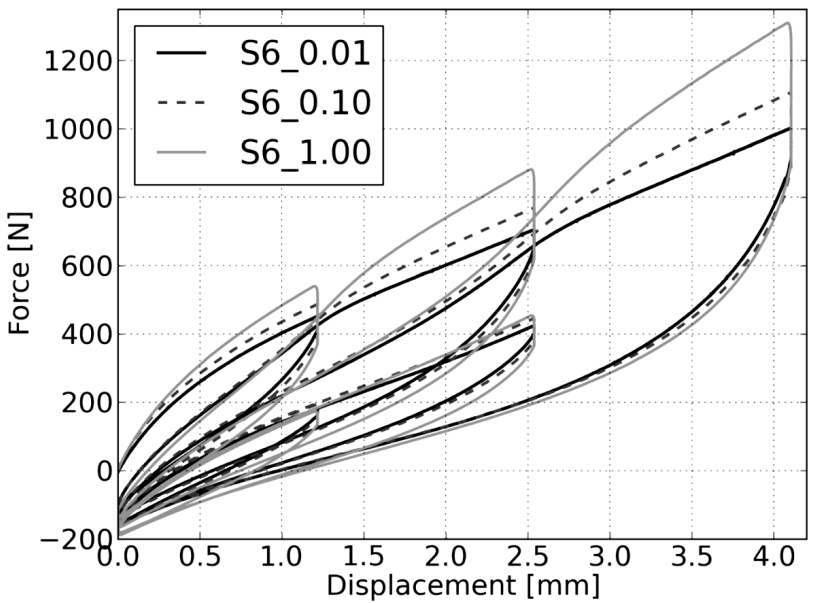

Figure 15: Force-displacement diagram, simple shear, various strain rates

Slika 15: Diagram sila-raztezek, enostavno striženje, različne hitrosti obremenjevanja

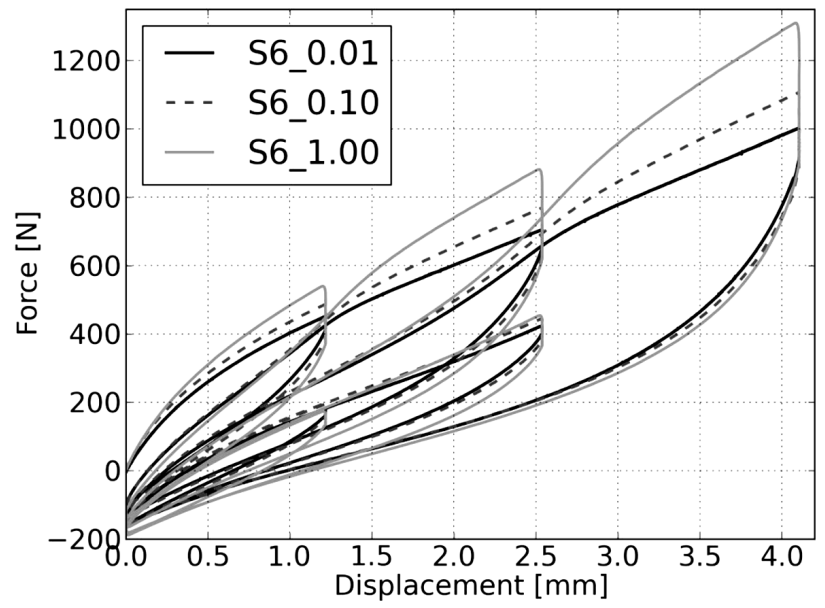

Figure 16: Force-displacement diagram, simple compression, various strain rates

Slika 16: Diagram sila-raztezek, enostavno tlačenje, različne hitrosti obremenjevanja 


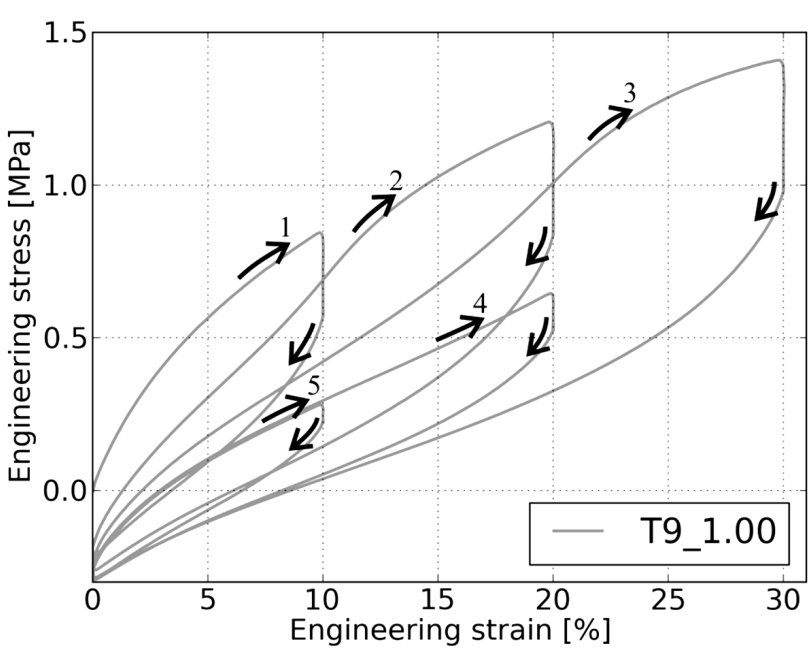

Figure 17: Stress-strain diagram, simple tension, cycle explanation Slika 17: Diagram napetost-raztezek, enostaven nateg, razlaga ciklov

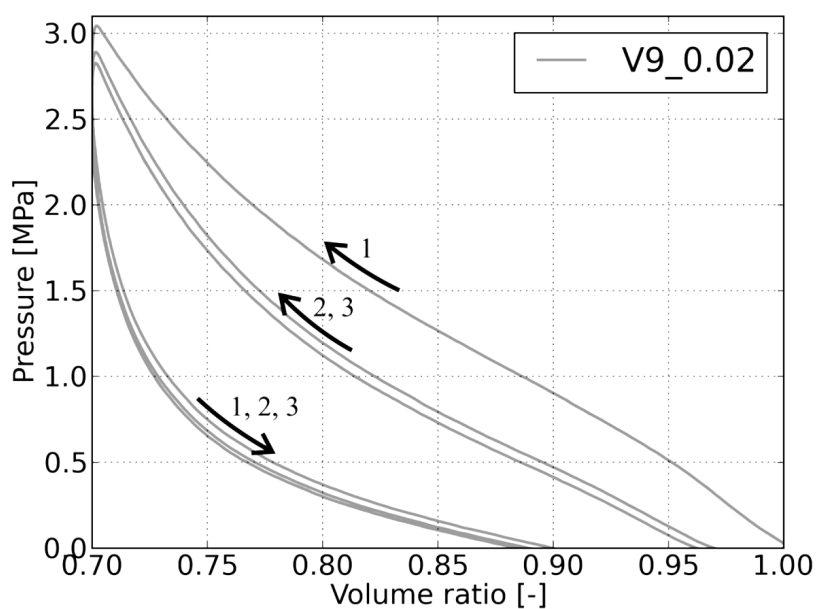

Figure 18: Volumetric compression, strain rate of $0.02 \mathrm{~s}^{-1}$ Slika 18: Volumetrično tlačenje, hitrost obremenjevanja $0,02 \mathrm{~s}^{-1}$

force decrease was approximately $30 \%$ during the relaxation time and if the relaxation time was longer, the force would still relax.

The force-displacement $(F-u)$ curves of the simple tests are shown in Figures 13 to 16. The sequence of the loading/unloading cycles is obvious from the stressstrain curve of the simple tension test in Figure 17. A significant influence of the strain rate on the $F-u$ curves is obvious in all the performed tests. Both hysteresis and stiffness increase with the strain rate.

The observed force-time/displacement diagrams can be converted (using the mentioned geometry of the samples) into stress-time/strain diagrams. Then, a closedform solution of the identification of the parameters of a large-strain viscoelastic constitutive model can be performed. However, a conversion with high accuracy is possible only in the case of simple tension. In the cases of simple compression and simple shear, the strain distribution is not homogeneous. Therefore, a more accurate identification process can be done using a numerical model where the $F$ - $t$ or $F-u$ curves of finite-element-method simulations are fitted to the experimental data. ${ }^{7,8}$

Figure 18 shows a pressure-volume ratio diagram of the volumetric compression test. Assuming a hydrostatic stress field, the value of the initial bulk modulus was determined to be $K=9.3 \mathrm{MPa}^{9}$

\section{CONCLUSIONS}

Experimental data for the identification of the parameters of the Bergstrom-Boyce model or other viscoelastic constitutive models of the ACM87 composite were obtained. Significant time-dependent behaviour of the material was proved. The amount of energy dissipated during the loading/unloading cycles (the area within the loops) demonstrates the suitability of the cork/rubber composite for damping.

\section{Acknowledgement}

This work was supported by the Ministry of Education, Youth and Sports of the Czech Republic under the project LO1506 PUNTIS, and by the Student Grant System SGS-2013-36.

\section{REFERENCES}

${ }^{1}$ R. Kottner, J. Vacík, R. Zemčík, Mater. Tehnol., 47 (2013) 2, 189-193

${ }^{2}$ V. Lašová, J. Vacík, R. Kottner, Procedia Engineering, 48 (2012), 358-366, doi:10.1016/j.proeng.2012.09.526

${ }^{3}$ J. Vacík, V. Lašová, R. Kottner, J. Káňa, Experimental determination of damping characteristics of hybrid composite structure, Proc. of the $48^{\text {th }}$ International Scientific Conference on Experimental Stress Analysis, Velké Losiny, 2010, 483-490

${ }^{4}$ J. S. Bergström, M. C. Boyce, Mechanics of Materials, 32 (2000) 11, 627-644, doi:10.1016/S0167-6636(00)00028-4

${ }^{5}$ A. Kossa, Effect of the modelling of lateral stretch in the parameters identification algorithm of hyperelastic foam materials, Proc. of the $31^{\text {st }}$ Danubia-Adria Symposium on Advances in Experimental Mechanics, Kempten, 2014, 141-142

${ }^{6}$ J. S. Bergström, Bergström-Boyce model, Material Models [online] 2015, available at https://polymerfem.com/content.php?77-bergstrom-boyce-model

${ }^{7}$ T. Kroupa, V. Laš, R. Zemčík, Journal of Composite Materials, 45 (2011) 9, 1045-1057, doi:10.1177/0021998310380285

${ }^{8}$ H. Srbová, T. Kroupa, R. Zemčík, Mater. Tehnol., 48 (2014) 4, 549-553

${ }^{9}$ S. Z. Qamar, M. Akhtar, T. Pervez, M. S. M. Al-Kharusi, Materials and Design, 45 (2013), 487-496, doi:10.1016/j.matdes.2012.09.020 